\title{
ESSENTIAL JOURNALS
}

\section{from International Universities Press}

JOURNAL OF THE AMERICAN PSYCHOANALYTIC ASSOCIATION

Edited by Theodore Shapiro

Founded in 1953 !

Noted for the outstanding quality of its articles on all aspects of psychoanalysis, JAPA continues to present contributions of vital concern to its readers. Published Quarterly.

1988. Individuals: $\mathbf{\$ 5 7 . 5 0 / I n s t i t u t i o n s : ~} \mathbf{\$ 7 0 . 0 0}$

INTERNATIONAL JOURNAL OF GROUP PSYCHOTHERAPY

\section{Edited by Robert R. Dies}

The IJGP, the official publication of the American Group Psychotherapy Association, has been a leading source of important information in the field for 35 years. Devoted to reporting and interpreting the research and practice of group psychotherapy, it reflects the diversity of work being done and promotes appropriate validation. Published Quarterly.

1988. Individuals: $\$ 49.00 /$ Institutions: $\$ 70.00$

PSYCHOANALYSIS AND CONTEMPORARY THOUGHT:

A Quarterly of Integrative and Interdisciplinary Studies Edited by Leo Goldberger

Aimed at broadening the scientific and intellectual horizon of psychoanalysis, this journal includes original clinical, theoretical, and experimental contributions integrating psychoanalysis with the social, biological, and behavioral sciences as well as the humanities. Published Quarterly.

1988. Individuals: $\$ \mathbf{5 2 . 5 0 / I n s t i t u t i o n s : ~} \$ 75.00$

JOURNAL OF GERIATRIC PSYCHIATRY: Official Journal of the Boston Society for Gerontologic Psychiatry

Edited by David Blau and Ralph J. Kahana

Designed for psychiatrists, psychologists, social workers, social scientists, and mental health personnel, this journal presents the latest thinking and most recent findings in geriatric psychiatry. Published Semiannually.

1988. Individuals: $\$ 38.00 /$ Institutions: $\$ 58.00$ INTERNATIONAL JOURNAL OF FAMILY PSYCHIATRY Edited by John G. Howells

Advancing the practice of family psychiatry, this journal serves as an international forum for all professionals interested in the family as a unit for evaluation and therapy. Published Quarterly. 1988. Individuals: $\$ 50.00 /$ Institutions: $\$ \mathbf{\$ 7} .00$

... and introducing two new journals from Sphinx Press SOVIET JOURNAL OF PSYCHOLOGY

Editor-in-Chief: B.F. Lomov, Director of the Institute of Psychology Associate Editors: V.S. Shustikov and L.I. Antsyferova This prestigious journal presents the more important Soviet studies in psychology, very carefully screened for high scientific standards, innovative approach, and current interest. Published Bimonthly.

1988. Individuals: $\$ 300.00 /$ Institutions: $\$ 575.00$

SOVIET PSYCHIATRY AND PSYCHOLOGY TODAY

Author-Compiler: V.S. Shustikov

Editors: B.F. Lomov, Corresponding Member of the USSR Academy of Sciences, and G.V. Morozov, Academician, Academy of Medical Sciences

Originating from the USSR, but in the English language, this new journal is the first of its kind. Not only does it contain the most significant articles in psychiatry and psychology appearing in the Soviet literature, which would otherwise not be translated into English, but one third of its content are articles by Russian authors written exclusively for this journal, in English. Published Quarterly.

1988. Individuals: $\$ 175.00 /$ Institutions: $\$ 345.00$

\section{Order from:}

INTERNATIONAL UNIVERSITIES PRESS/SPHINX PRESS

Dept. SL740, 59 Boston Post Road, Madison, CT 06443-1524

Note: Foreign subscribers please add $\mathbf{S 1 0}$. per volume for IUP journals. definitely marks a major improvement over the original version.-James W. Geary, Kent State University, Ohio.

\section{Information Technology and Information} Use: Towards a Unified View of Information and Information Technology. Ed. by Peter Ingwersen, Leif Kajberg, and Annelise Mark Pejtersen. London: Taylor Graham, 1986. 194p. \$37 (ISBN 0-947568-06-9).

This volume comprises thirteen papers presented at a seminar entitled "Information Technology as a Tool for Information Use" at the Royal School of Librarianship, Copenhagen, in May 1985. The seminar was international in scope and produced papers on diverse topics, but, as a collection of such, this volume fails to present the unified view of information science theory or practice that is suggested by the subtitle. In fact, there are several conflicting viewpoints presented in the various papers.

Well-known authors in information science, such as F. W. Lancaster and Blaise Cronin, have contributed to this collection. The papers are organized under three themes: (1) "Socio-Economic Aspects and Policy-Making"; (2) "Information Systems Design: Pragmatic Issues"; and (3) "Education for Information." Lancaster has contributed an excellent introduction in which he raises several important questions concerning the present state of information technology and accessibility to information. He expresses his doubt that subject specialists have any better access to the relevant literature in their fields than they had before the advent of computerized information systems. He also predicts a vital role for the information gatekeepers of the future. Both of these viewpoints are contradicted by other authors.

Common themes addressed in this volume are the difficulty of measuring qualitative and quantitative contributions of information and information technology in organizations, the debate concerning generalization versus specialization in library and information science education, and the question of whether there will be greater or lesser future roles for librarians 


\section{The Sabin Collection: $A$ history of the Western Hemisphere, on microfiche.}

Unparalleled in breadth and depth, The Sabin Collection from Research Publications is based on Joseph Sabin's Bibliotheca Americana: A Dictionary of Books Relating to America from its Discovery to the Present Time.

Materials published in Europe, South and Central America, the United States and Canada include topics and events such as Columbus' discovery of America, Spanish explorations and conquests, the Revolutionary War, the pioneering of Canada, the Western movement, Native American Indians, slavery and abolition, the exploration of Arctica and Antarctica, and much, much more. The collection contains a wealth of primary source materials on literature, economics, politics, agriculture and other subjects.

The Sabin Collection is an ongoing project of Research Publications, with approximately $15 \%$ of the bibliographic titles filmed. The collection is supplemented annually with 600 volumes of additional material. For further information use the form below. Or call 1-800-REACH-RP (1-800-732-2477) now. From Connecticut, Alaska and Canada, call collect 203-397-2600.

sead me information on P prodects and serrices at

mericana

bllections in

ficroform

esearch

ollections in

ficroform

glevision News

ranscripts and

idexes

iternational

ewspapers on

icrofilm

ewspaper

dexes

purnals in

ficroform

S. and

ternational

btent

pcumentation

atent Search

hd Awareness
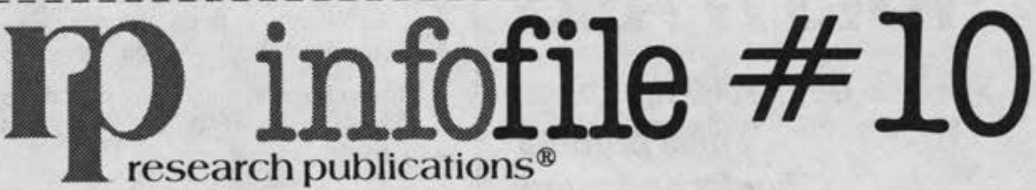

12 Lunar Drive/Drawer AB Woodbridge, CT 06525 Toll-free: 1-800-REACH-RP TWX: 710-465-6345 FAX: 203-397-3893

$\square$ Please send me more information on The Sabin Collection. $\square$ Please have a sales representative call me.

\begin{tabular}{lll}
\hline Name & Title & \\
\hline Institution & & \\
\hline Address & & \\
\hline City & State & Zip Code \\
\hline
\end{tabular}

Phone

For further information, or to place your order directly, call 1-800-REACH-RP (1-800-732-2477). 
and information intermediaries in light of advances in information technology. Business, industrial, and educational settings are discussed.

The papers presented under the topic "Education for Information" will be of greatest interest to an academic readership. Both optimistic and rather critical viewpoints are expressed concerning the present state of educational programs. Leif Kajberg discusses the restructured library and information science curriculum at the Royal School of Librarianship and concludes that the past program was inadequate for successful preparation of students for future information professions. He bemoans the liberal arts background of the majority of students: they lack quantitative skills, and a high proportion of them are "reading-oriented, introvert and handicapped in some way or other." Cronin also suggests changes in existing educational structures for the education of "electronic librarians." Irene Wormell describes the current state of library and information science education as "chaotic and controversial" and stresses specialization in education for the information professions. Ann Irving discusses the U.K. Microelectronics Education Programme for primary school education and suggests that information professionals will become obsolete as future citizens become their own information managers. She raises the rather absurd question of whether children should continue to be taught to write in light of speech recognition and communications technology.

On the theme "Information Systems Design," Lancaster discusses the evaluation of information services and the difficulty of measuring cost-effectiveness in their provision. Linda C. Smith describes knowledge-based systems and artificial intelligence and defines associated terminology. Peter Bogh Anderson presents an interesting set of metaphors to describe interaction between humans and automated systems from the point of view of computers as media. Another topic addressed in this section is human factors and their relevance to information systems design.

\section{With Biological Abstracts/RRM (Reports, Reviews, \\ $B A / R^{\circ}$ \\ HAS ITALL! \\ Over 1600 meetings, plus patents, books and more! \\ Meetings) you'll receive 250,000 entries for 1987 from over 9.000 serials and other publications from over 100 countries. \\ No other reference publication provides you with comprehensive coverage of symposia papers, meet- ing abstracts, review publications, bibliographies. research communications, books, book chapters and U.S. patents. In three easy-to-use sections-Content Summaries, Books and Meetings. \\ The indexes in each issue provide four modes of access to the literature: Author, Biosystematic, Generic and Subject. \\ Take advantage of this excellent coverage of impor- tant new scientific research and discoveries for your library. \\ Make sure your library has it all! Subscribe today by contacting BioSciences Information Service (BIOSIS*) Customer Services, 2100 Arch Street, Philadelphia, PA 19103-1399 USA. Tele- phone (215) 587-4800 worldwide or toll free (800) 523-4806 (USA, except AK, HI, PA). Or contact the Official Representative in your area.}




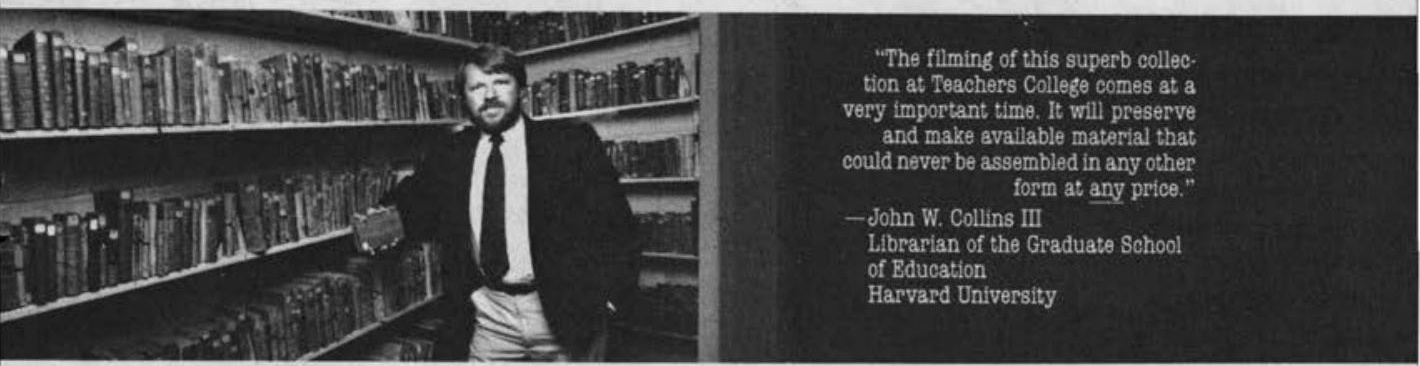

\section{The Fistory of Fducation collection, spanning five centuries, now on microfiche.}

One comprehensive source for virtually every aspect of the study of education from Research Publication.

Filmed from the holdings of Milbank Memorial Library of Teachers College at Columbia University, this noted collection provides scholars and researchers with rare insight into educational theories and practices from the 15th through the 19th centuries.

With more than nine thousand international treatises, organized into units of 1,250 microfiche each, this collection provides material for both undergraduate and graduate studies in area such as psychology, philosophy, guidance and counseling, special education, and administration. The collection also provides opportunities in other fields such as sociology, communications, religion and women's studies.

For further information use the form below. Or call 1-800-REACH-RP (1-800-732-2477) now. From Connecticut, Alaska and Canada, call collect 203-397-2600.

lease send me
nfformation on other
$3 P$ products and
ervices checked:
Research
Collections in
Microform
Television News
Transcripts and
Indexes
International
Newspapers on
Microfilm
Newspaper
Indexes
Journals in
Microform
U.S. and
International
Patent

please send me
hformation on $3 P$ products and services checked: Collections in Transcripts and Indexes Newspapers on rofilm Documentation Patent Search

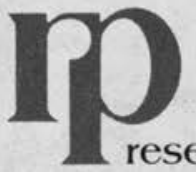

12 Lunar Drive/Drawer $A B$ Woodbridge, CT 06525 Toll-free: 1-800-REACH-RP TWX: $710-465-6345$ FAX: 203-397-3893

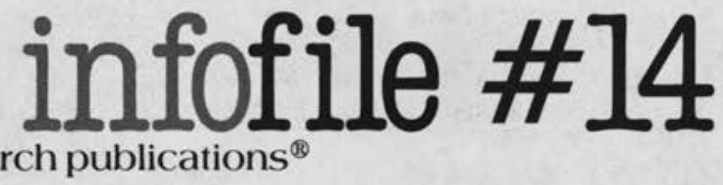

$\square$ Please send me more information on The History of Education Collection.

$\square$ Please have a sales representative call me.

\begin{tabular}{lll}
\hline Name & \multicolumn{2}{c}{ Title } \\
\hline Institution & & \\
\hline Address & & \\
\hline City & State & Zip Code \\
\hline Phone & &
\end{tabular}

For further information, or to place your order directly, call 1-800-REACH-RP (1-800-732-2477). 
The papers presented under the topic "Socio-Economic Aspects and PolicyMaking" are primarily concerned with cost/benefit models for information services and quantitative contributions of information and information technology to productivity in business and industry. Inge Berg Hansen discusses the need for national information policies and the de- sign of one such policy in Denmark.

On the whole, this volume does not provide a comprehensive overview of the field: it is a haphazard collection that presents diverse opinions on different aspects of information and information technology in the public and private sectors.Dana S. Edwards, University Library, University of Illinois at Chicago.

\section{OTHER PUBLICATIONS}

American Art Directory. Ed. by Jacques Cattell Press. New York: Bowker, 1987. 765p. $\$ 94.50$ (ISBN 0-8352-2218-7).

Applied Social Sciences Index \& Abstracts. V.1. Ed. by P. F. Broxis. London: Library Assn., 1987. 264p. subscription, $\$ 756$.

ARBA Guide to Library Science Literature 1970-1983. Ed. by Donald G. Davis and Charles D. Patterson. Littleton, Colo.: Libraries Unlimited, 1987. 682p. \$65 (ISBN 087287-585-7). LC 86-27712.

Asian Economic Handbook. Detroit: Gale, 1987. 272p. $\$ 80$ (ISBN 0-86338-141-3).

Beckman, Robert I. Find It Fast. New York: Harper, 1987. 260p. paper, $\$ 6.95$ (ISBN 0-06096153-8).

BioScan: The Biotechnology Corporate Service. Ed. by Oryx Pr. Phoenix: Oryx, 1987. 400p. $\$ 425$.

Book Review Index: 1986 Cumulation. V.22. Ed. by Barbara Beach. Detroit: Gale, 1987. 1,196p. $\$ 170$ (ISBN 0-8103-0578-X). LC 65-9908.

Boswell, Jeanetta. Spokesman For The Minority ... A Bibliography of Sidney Lanier, William Vaughn Moody, Henry Timrod, Frederick Goddard Tuckerman, and Jones Very, with Selective Annotations. Metuchen, N.J.: Scarecrow, 1987. 306p. \$29.50 (ISBN 0-8108-1944-9).

Burns, Grant. The Sports Pages: A Critical Bibliography of Twentieth-Century American Novels and Stories Featuring Baseball, Basketball, Football, and Other Athletic Pursuits. Metuchen, N.J.: Scarecrow, 1987. 284p. \$25 (ISBN 08108-1966-X).

CD Review Digest. V.1. Ed. by Janet Grimes. Vooheesville, N.Y.: Peri Pr., 1987. 200p. \$39.

Cassutt, Michael. Who's Who In Space: The First 25 Years. Boston: G. K. Hall, 1987. 336p. \$35 (ISBN 0-8161-8801-7).

The Center for Research Libraries Handbook. Chicago: Center for Research Libraries, 1987. 161p.

Consumer Sourcebook. 4th ed. suppl. Ed. by Kay Gill and Robert Wilson. Detroit: Gale, 1987. 217p. paper, \$85 (ISBN 0-8103-0371-X).
Contemporary Authors: A Bio-Bibliographical Guide to Current Writers in Fiction, General Nonfiction, Poetry, Journalism, Drama, Motion Pictures, Television, and Other Fields. V.120. Ed. by Hal May. Detroit: Gale, 1987. 756p. $\$ 90$ (ISBN 0-8103-1920-9). LC 62-52046.

Contemporary Authors Autobiography Series. V.5. Ed. by Adele Sarkissan. Detroit: Gale, 1987. 483p. \$85 (ISBN 0-8103-4504-8).

Contemporary Graphic Artists. V.1. Ed. by Maurice Horn. Detroit: Gale, 1987. 272p. \$50 (ISBN 0-8103-2189-0).

Contemporary Literary Criticism: Excerpts from Criticism of the Works of Today's Novelists, Poets, Playwrights, Short Story Writers, Scriptwriters, and Other Creative Writers. V.42. Ed. by Daniel G. Marowski and Roger Matuz. Detroit: Gale, 1987. 771p. $\$ 90$ (ISBN 0-81034416-5). LC 76-38938.

Contemporary Newsmakers 1986. Ed. by Peter M. Gareffa. Detroit: Gale, 1987. 445p. \$70 (ISBN 0-8103-2202-1).

Cortez, Edwin M. Proposals and Contracts for Library Automation: Guidelines for Preparing RFP's. Chicago: Pacific Information, 1987. 224p. paper, \$29 (ISBN 0-8389-2043-8). LC 8630664.

Der Ruf: Zeitung der Deutschen Kriegsfangenen in USA. New York: Saur, 1987. 232p. \$89 (ISBN 3-598-10663-7).

Dictionary of Literary Biography Yearbook: 1986. Ed. by J. M. Brook. Detroit: Gale, 1987. 435p. \$95. (ISBN 0-8103-2094-0). LC 82-645185.

Directory of American Research and Technology 1987. Ed. by Jacques Cattell Pr. New York: Bowker, 1987. 744p. \$185 (ISBN 0-835223108).

Directory of Grants in the Humanities, 1987. Ed. by Oryx Pr. Phoenix: Oryx, 1987. 425p. $\$ 74.50$ (ISBN 0-89774-358-X).

Directory of Hong Kong Industries 1987. Comp. by Hong Kong Productivity Council. Detroit: Gale, 1987. 839p. $\$ 100$.

The Economics of Online. V.2. Ed. by Peter Bysouth. London: Taylor Graham, 1987. 229p. 